\title{
Semiotics of mathematics problem-solving in Mason's generalization
}

\author{
Ihda Mutimmatul Fitriyah 1, a, *, Yuni Arrifadah 1, b, Siti Lailiyah 1,c \\ ${ }^{1}$ Department of Mathematics Education, Universitas Islam Negeri Sunan Ampel Surabaya \\ Jalan Jendral Ahmad Yani 117, Surabaya 60237, Indonesia \\ E-mail: ${ }^{a}$ ihdamutimmatulfitriyah@gmail.com, ${ }^{b}$ yuniarrifadah@uinsby.ac.id, ${ }^{\mathrm{c}}$ lailiyah@uinsby.ac.id \\ * Corresponding Author
}

\section{ARTICLE INFO}

Article history

Received: 24 March 2021

Revised: 28 April 2021

Accepted: 18 May 2021

\section{Keywords}

Semiotics, gesture, word symbols, Mason's generalization, mathematics generalization

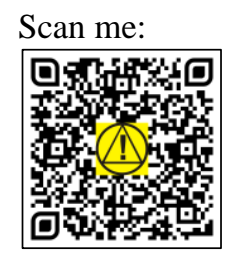

\section{ABSTRACT}

Semiotics are signs that include codes, symbols, words, icons, objects, or gestures. This descriptive-qualitative study aimed to describe the semiotics of mathematics problem-solving in Mason's generalization. Generalization is a finding pattern process in which students will use the different strategies with some semiotics. The subjects were three of 30 eleventh graders from a senior high school in Gresik Regency, Indonesia, that were selected using the purposive sampling technique. Data was collected through documentation, written test, and interview. Data was analyzed by reducing data, presenting data, and concluding. The results of this study showed that students could present the semiotics of gesture, word, and symbols in the process of Mason's generalization, even though in several stages or indicators the students could not present semiotics. The absence of semiotics in several stages or indicators was not because students could not do such things, but because students passed or skipped these stages. In the perception of generality stage, the semiotics of gesture, word, and symbols could emerge simultaneously. However, for expression of generality, symbolic expression of generality, and manipulation of generality stage, students did not present the three semiotics' components simultaneously.

How to Cite: Fitriyah, I. M., Arrifadah, Y., \& Lailiyah, S. (2021). Semiotics of mathematics problem-solving in Mason's generalization. Jurnal Riset Pendidikan Matematika, 8(1), 1-21. https://doi.org/10.21831/jrpm.v8i1.39621

\section{INTRODUCTION}

Semiotics represent signs which could include codes, symbols, words, icons, objects, or gestures. These signs can be detected by the five human senses, have implicit meanings, and play an important role in the communication process (Sardila, 2016, p. 89). Suryaningrum (2018, p. 9) argues that the meaning of these signs can emerge when someone is involved in communication activities. Therefore, semiotics is the most important aspect of communication, especially in mathematics. Some researchers divide semiotics into several types or components, one of which is Inganah and Subanji (2013, p. 433) who divide semiotics into three components, namely gesture, word, and symbols.

A gesture is the most important part of communication because, with the gesture, mathematical ideas can be communicated (Alibali \& Nathan, 2012, p. 248; Dwijayanti et al., 2019, p. 134). Faradiba et al. (2016, p. 881) stated that various kinds of gestures (hand movements and facial expressions) helped students communicate verbally. Gestures can be in the form of gestures either from the fingers, hands, arms, or other body parts that accompany spoken communication to emphasize and reduce the ambiguity of the information conveyed (Damayanti, 2018; Ibraheem \& Khan, 2012). In this study, the type of gesture observed was the one developed by Alibali and Nathan (2012) and Ruhama et al. (2018) which includes (1) pointing gesture, that is the motion of pointing to an object, subject, or place with fingers, writing tools, or other pointing tools; (2) representational gesture, that is a motion that represents objects, concepts, relations with the intention that can be understood by other people; and (3) writing gesture, that is a writing motion that occurs simultaneously with speech. The three types of gestures were chosen 


\section{Jurnal Riset Pendidikan Matematika, 8 (1), 2021 - 2}

Ihda Mutimmatul Fitriyah, Yuni Arrifadah, Siti Lailiyah

because, in the study process, the three gestures are easy to observe and suitable for analyzing the student generalization process.

Word represents statements in the form of words or sentences, not signs or symbols, either orally or in writing, during the generalization process. For example, students state the difference in the pattern between the circle pictures with the phrase "increase by two circles in each pattern", "in each pattern, it tripled" or write the sentence "thus, the number of circles in the fourth pattern is 20 ", and so on. The word that the student expresses or writes accompanies the gesture so that the word and the gesture in the generalization process correspond well (Inganah \& Subanji, 2013, pp. 434-435).

Symbols in pattern generalization are formed by students through the internalization process. Students make symbols through their observations of existing patterns and then identify the similarities or differences of the patterns. Symbols formed by students in generalizing patterns are very useful, especially for variable recognition (Inganah \& Subanji, 2013, p. 433). In addition, the existence of symbols formed by students indicates the efforts made by students to understand what they are learning or solving (Oers, 2010, p. 31). Symbols are signs based on conventions, rules, or agreements that have been mutually agreed upon (Sumbo, 2009, p. 19). This means that the symbol will be understood if students already understand the meaning of the symbol that has been agreed upon previously. The semiotics in the form of symbols referred to in this study are mathematical signs, notations, or symbols formed by students during the generalization process.

Semiotics has its own relationship with mathematics because mathematics is knowledge related to an activity-based sign (Fadiana et al., 2018, p. 99). This implies that in mathematics learning, there is a certain semiotic. Tarasenkova and Kovalenka $(2015$, p. 32) assert the existence of semiotics that accompany the process of understanding abstract mathematical contexts. One of the mathematical processes that can lead to certain semiotics is the generalization process. This happens because in the generalization process students use different strategies and are accompanied by semiotics (signs) (Fadiana et al., 2018, p. 99).

Generalization means obtaining something general in nature, a means of thinking and communicating, and concluding (Anggoro, 2016, p. 13; Lesmana et al., 2018, p. 864; Sadieda et al., 2018, p. 132). Generalization is the process of finding a general or broader pattern (Sadieda et al., 2018, p. 132). Mason et al. (2010) state that generalization is the process of looking for patterns and the general connection and making connections in the various levels of mathematical thinking. Mason (1996) divides generalizations into four stages, namely (1) perception of generality; (2) expression of generality; (3) symbolic expression of generality; and (4) manipulation of generality.

The perception of the generality stage is characterized by students recognizing a pattern, identifying the pattern, and recognizing that the problem can be solved using a pattern. The expression of generality stage is characterized by students being able to describe the pattern well and use it to determine the next term. The symbolic expression of the generality stage is characterized by students producing general patterns and being able to symbolically formulate generality. Lastly, the manipulation of the generality stage is characterized by students using general patterns to solve problems (Ramdhani, 2018, p. 84).

The importance of generalization in mathematics learning is evidenced by the existence of basic competencies in the Curriculum 2013, the national curriculum of Indonesia, which indicates that generalizing patterns should be achieved by junior and senior high school students (Ministry of Education and Culture, 2016). Likewise with the National Council of Teachers of Mathematics (NCTM) recommends ideas related to algebraic reasoning through generalizing patterns in primary and secondary schools (NCTM, 2020). Nonetheless, previous studies have shown that in solving number pattern problems, students often experience obstacles or difficulties including the inability of students to understand the $n$-th term $\left(U_{n}\right)$ formula of arithmetic and geometric sequences, difficulties in converting number pattern problems into mathematical models, and difficulties to discovering the general pattern of a sequence of abstract object configurations (Handayani et al., 2015; Marion et al., 2015; Octriana et al., 2019; Sari et al., 2016).

Several studies and reviews related to pattern generalization show that students use different strategies, stages, or processes in solving pattern generalization problems. The study conducted by Setiawan et al. (2020, pp. 91-92) demonstrates that students use recursive strategy (changing a pictorial pattern into a number pattern, finding a common difference contained in the pattern, using the common difference and the first term to determine the second term, using the common difference and the second 
term to determine the third term and so on until students obtain a general pattern) and differentiation strategy (changing a pictorial pattern into a number pattern, finding a common difference in the pattern, interpreting the common difference as a jump of numbers, and analyzing the connection between the first term and the common difference so that students obtain the general pattern they are looking for) in generalizing the pattern. Inganah and Subanji (2013) and Radford (2007) found that students use three strategies to generalize patterns, namely algebraic generalization, arithmetic generalization, and trial and error. Of the three strategies, only algebraic generalizations were identified as the emergence of semiotics, because in the process there are three stages, namely factual, conceptual, and symbolic. While the results of the study conducted by Fadiana et al. (2018) reveal that in generalizing a pattern, students go through four stages, namely discovering a regularity, confirming the regularity, generating a general formula, and proving the truth of the general formula accompanied by semiotics in the form gestures, words, and symbols. The study of Fadiana et al. (2018), however, focused on the generalization process rather than describing in detail how and what semiotics are generated in the generalization process.

Based on the description of what has been done and found by several previous studies, Setiawan et al. (2020), Inganah and Subanji (2013), Radford (2007), Fadiana et al. (2018) employed strategies, stages, or processes of generalization that are different from one another. In this study, we prefer to use the strategies or stages of Mason's generalization which are broadly more complex because they include the strategies and stages used by Setiawan et al. (2020), Inganah and Subanji (2013), Radford (2007), and Fadiana et al. (2018). In addition, the novelty of this study lies in its focus, namely semiotics, where when we viewed from the studies of Inganah and Subanji (2013) and Radford (2007), they only identify the existence of semiotics in one generalization strategy. As for this study, we analyzed the semiotics as a whole at each stage of Mason's generalization. This is expected to be able to provide new knowledge for teachers in preparing learning designs or models by considering the students' semiotics that emerges in Mason's generalizations. The more critical the teacher's knowledge regarding the student's semiotics of mathematics problem-solving in Mason's generalization, the more creative the teacher will be in preparing learning designs that can make students more diligent, active, and productive in learning mathematics. Accordingly, this study aimed at describing the semiotics (gesture, word, and symbols) of mathematics problem-solving in Mason's generalization. The results of this study are expected to be an additional reference for the teachers and researchers in developing semiotics and generalizations that students have through mathematics learning.

\section{METHOD}

This descriptive study with a qualitative approach aimed to describe the semiotics of mathematics problem-solving in Mason's generalization. This study involved students of class XI IPA 1 (eleventh graders of science program) at SMA Assa'adah Gresik, East Java Province, Indonesia, in the second semester of the 2019/2020 academic year. The purposive sampling technique was used in the selection of three students from 30 students as the subject of this study. The selection of the three students was based on two considerations that we have set, namely, students have high mathematical abilities based on the results of the assessment on basic competencies related to number pattern and have good communication skills based on the opinions of the mathematics teacher and form teacher who know the students better. With these criteria, the selected students were expected to be able to pass Mason's generalization stages, so that we can discover and describe the semiotics that appears at each stage. The three students were then assigned distinctive codes, namely subject A, subject B, and subject $\mathrm{C}$, for assuring the confidentiality and privacy of the subject.

We collected data on semiotics in mathematics problem-solving through video documentation, written test, and interview. Video documentation was carried out to obtain gesture data that emerged in Mason's generalization during the study. The written test employed a constructed-response question with the topic of number pattern that is selected and adapted from the question made by Barbosa et al. (2007) as presented in Figure 1. We used this type of question to obtain semiotic data in the form of words and gestures that appear in Mason's generalization. The written test was carried out at the same time in one place, but among the three subjects were spaced so that they were more focused and did not interfere with each other. Each student was accompanied by one person as a research assistant to document student behavior during the written test. Before accompanying each student, we first provided 


\section{Jurnal Riset Pendidikan Matematika, 8 (1), 2021 - 4}

Ihda Mutimmatul Fitriyah, Yuni Arrifadah, Siti Lailiyah

direction to the three research assistants so that they do not make the wrong documentation. The duration of the written test was 60 minutes.

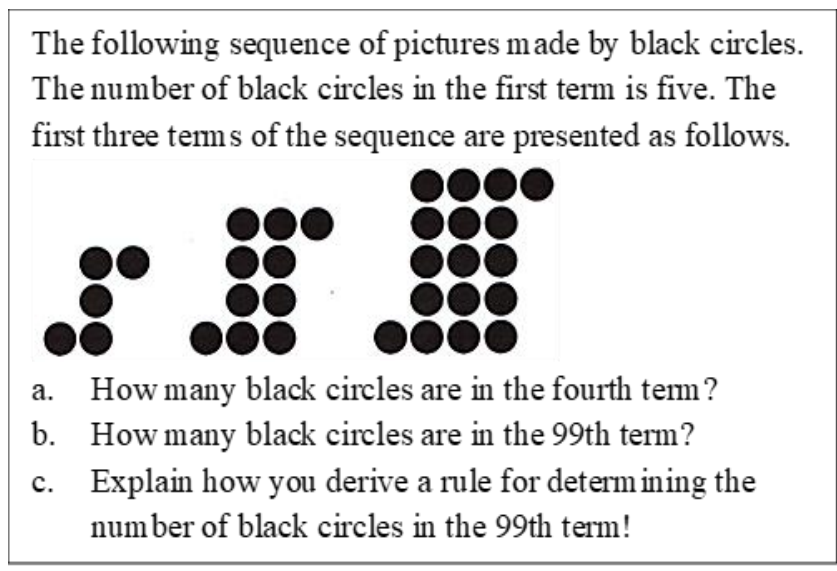

Figure 1. Constructed response question that was employed in the test

In this study, we conducted a semi-structured interview which was conducted after the implementation of the written test. The interview for the three students was carried out in turns in a different place from the written test so that when one student conducted an interview, the other students did not hear the ongoing interview process. This interview was conducted by the researcher himself. The questions posed in the interview were structured and made by adjusting the possible semiotic components made by students in Mason's generalization. Examples of questions used in interviews such as: (1) "What strategy did you use in solving the problems?"; (2) "Please explain the pattern you found in the question!"; dan (3) "Please explain how you could generalize the pattern $\left(U_{n}\right)$ !".

The written test research instrument and interview guidelines have been validated by three experts in the field of algebra and mathematics learning with feedback related to changes in interview sentences to make it more efficient and strive for one indicator for one solution to make it easier to describe the subject's answer. The conclusion obtained from the validation results was that the instrument was suitable for use with revision for improvement. The possibility of students' semiotic components in Mason's generalization used in this study is presented in Table 1 to Table 4.

Table 1. Possible semiotics components in the perception of generality

\begin{tabular}{lll}
\hline Code & $\begin{array}{l}\text { Semiotics } \\
\text { component }\end{array}$ & $\begin{array}{l}\text { Description } \\
\text { T1.1 }\end{array}$ \\
Gesture & $\begin{array}{l}\text { There is a pointing gesture, representational gesture, or writing } \\
\text { gesture when writing down what is known and asked in the problem } \\
\text { Where is a word or sentence (spoken or written communication) when } \\
\text { understanding what is known and asked in the problem } \\
\text { There is a written mathematical sign, notation, or symbol when } \\
\text { writing whatever is known and asked in the problem } \\
\text { There is a pointing gesture, representational gesture, or writing } \\
\text { gesture when identifying patterns on the problem } \\
\text { There is a word or sentence (spoken or written communication) when } \\
\text { expressing that a problem can be solved with a pattern recognition } \\
\text { There is a written mathematical sign, notation, or symbol when } \\
\text { identifying pattern on the problem }\end{array}$ \\
\hline
\end{tabular}


Jurnal Riset Pendidikan Matematika, 8 (1), 2021 - 5

Ihda Mutimmatul Fitriyah, Yuni Arrifadah, Siti Lailiyah

Table 2. Possible semiotics components in the expression of generality

\begin{tabular}{|c|c|c|}
\hline Code & $\begin{array}{l}\text { Semiotics } \\
\text { component }\end{array}$ & Description \\
\hline \multirow[t]{3}{*}{$\overline{\mathrm{T} 2.1}$} & Gesture & $\begin{array}{l}\text { There is a pointing gesture, representational gesture, or writing } \\
\text { gesture when describing a pattern }\end{array}$ \\
\hline & Word & $\begin{array}{l}\text { There is a word or sentence (spoken or written communication) when } \\
\text { describing a pattern }\end{array}$ \\
\hline & Symbols & $\begin{array}{l}\text { There is a written mathematical sign, notation, or symbol when } \\
\text { describing a pattern }\end{array}$ \\
\hline \multirow[t]{3}{*}{$\mathrm{T} 2.2$} & Gesture & $\begin{array}{l}\text { There is a pointing gesture, representational gesture, or writing } \\
\text { gesture when determining the next term (of a sequence) }\end{array}$ \\
\hline & Word & $\begin{array}{l}\text { There is a word or sentence spoken or written communication) when } \\
\text { determining the next term (of a sequence) }\end{array}$ \\
\hline & Symbols & $\begin{array}{l}\text { There is a written mathematical sign, notation, or symbol when } \\
\text { determining the next term (of a sequence) }\end{array}$ \\
\hline
\end{tabular}

Table 3. Possible semiotics components in the symbolic expression of generality

\begin{tabular}{|c|c|c|}
\hline Code & $\begin{array}{l}\text { Semiotics } \\
\text { component }\end{array}$ & Description \\
\hline \multirow[t]{3}{*}{ T3.1 } & Gesture & $\begin{array}{l}\text { There is a pointing gesture, representational gesture, or writing } \\
\text { gesture in the process of finding a general pattern by symbolically } \\
\text { formulating the process }\end{array}$ \\
\hline & Word & $\begin{array}{l}\text { There is a word or sentence (spoken or written communication) in } \\
\text { the process of finding a general pattern by symbolically formulating } \\
\text { the process }\end{array}$ \\
\hline & Symbols & $\begin{array}{l}\text { There is a written mathematical sign, notation, or symbol in the } \\
\text { process of finding a general pattern by symbolically formulating the } \\
\text { process }\end{array}$ \\
\hline \multirow[t]{3}{*}{ T3.2 } & Gesture & $\begin{array}{l}\text { There is a pointing gesture, representational gesture, or writing } \\
\text { gesture when finding a general pattern }\left(U_{n}\right) \text { and formulating it } \\
\text { symbolically }\end{array}$ \\
\hline & Word & $\begin{array}{l}\text { There is a word or sentence (spoken or written communication) when } \\
\text { finding a general pattern }\left(U_{n}\right) \text { and formulating it symbolically }\end{array}$ \\
\hline & Symbols & $\begin{array}{l}\text { There is a written mathematical sign, notation, or symbol when } \\
\text { finding a general pattern }\left(U_{n}\right) \text { and formulating it symbolically }\end{array}$ \\
\hline
\end{tabular}

We analyzed the data collected in stages consisting of data reduction, data presentation, and concluding (Moleong, 2013). We analyzed the data from the written test results by correcting the results of the written test using the answer key, classifying the results of the written test with Mason's generalization indicator, describing and analyzing the results of the written test by data triangulation, and drawing conclusions based on Table 1 to Table 4 . As for the interview data, we analyzed it by replaying the recorded interview results, making the interview transcripts obtained, and reducing the results of the interview transcripts by giving codes as shown in Table 5. Finally, we analyzed the documentation data by playing back the documentation video recordings; taking a certain part of the video where the student shows the pointing gesture, representational gesture, and writing gesture; and transcribing part of the video by assigning codes as shown in Table 5. We double-checked to ensure the consistency of the results of the transcript coding obtained, then we describe and analyze interview and documentation data by employing data triangulation and draw conclusions based on Table 1 to Table 4 .

In data analysis, data triangulation was carried out to compare whether each data originating from written tests, interviews, and documentation was consistent. If the data from the three sources have the same, then the data is valid. If it is found that there is a mismatch of data from these sources, then we re-interviewed students to find consistent answers, so that the research objectives can be achieved. 
Jurnal Riset Pendidikan Matematika, 8 (1), 2021 - 6

Ihda Mutimmatul Fitriyah, Yuni Arrifadah, Siti Lailiyah

Table 4. Possible semiotics components in the manipulation of generality

\begin{tabular}{|c|c|c|}
\hline Code & $\begin{array}{l}\text { Semiotics } \\
\text { component }\end{array}$ & Description \\
\hline \multirow[t]{3}{*}{$\mathrm{T} 4.1$} & Gesture & $\begin{array}{l}\text { There is a pointing gesture, representational gesture, or writing } \\
\text { gesture when reconsidering and re-examining the solution }\end{array}$ \\
\hline & Word & $\begin{array}{l}\text { There is a word or sentence (spoken or written communication) when } \\
\text { reconsidering and re-examining the solution }\end{array}$ \\
\hline & Symbols & $\begin{array}{l}\text { There is a written mathematical sign, notation, or symbol when } \\
\text { reconsidering and re-examining the solution }\end{array}$ \\
\hline \multirow[t]{3}{*}{$\mathrm{T} 4.2$} & Gesture & $\begin{array}{l}\text { There is a pointing gesture, representational gesture, or writing } \\
\text { gesture when using general pattern }\left(U_{n}\right) \text { for problem-solving }\end{array}$ \\
\hline & Word & $\begin{array}{l}\text { There is a word or sentence (spoken or written communication) when } \\
\text { using general pattern }\left(U_{n}\right) \text { for problem-solving }\end{array}$ \\
\hline & Symbols & $\begin{array}{l}\text { There is a written mathematical sign, notation, or symbol when using } \\
\text { general pattern }\left(U_{n}\right) \text { for problem-solving }\end{array}$ \\
\hline \multirow[t]{3}{*}{$\mathrm{T} 4.3$} & Gesture & $\begin{array}{l}\text { There is a pointing gesture, representational gesture, or writing } \\
\text { gesture when concluding the solution to the problem }\end{array}$ \\
\hline & Word & $\begin{array}{l}\text { There is a word or sentence (spoken or written communication) when } \\
\text { concluding the solution to the problem }\end{array}$ \\
\hline & Symbols & $\begin{array}{l}\text { There is a written mathematical sign, notation, or symbol when } \\
\text { concluding the solution to the problem }\end{array}$ \\
\hline
\end{tabular}

Table 5. Coding for interview and documentation data

\begin{tabular}{|c|c|c|c|}
\hline Source of data & Coding & \multicolumn{2}{|c|}{ Description } \\
\hline \multirow{6}{*}{$\begin{array}{l}\text { Video } \\
\text { documentation }\end{array}$} & [Figure] & $\mathrm{a}$ & : The order of figure \\
\hline & Figure a. b Subject $\mathrm{X}$ in Td. e & $\mathrm{b}$ & : Type of gesture that appears \\
\hline & & $\mathrm{X}$ & : The subject of study, $X=A, B, C$ \\
\hline & & $\mathrm{T}$ & : Mason's generalization stage \\
\hline & & & $\begin{array}{l}\text { The d-th stage of Mason's generalization, } \\
d=1,2,3,4\end{array}$ \\
\hline & & & $\begin{array}{l}\text { The e-th indicator of each stage of } \\
\text { Mason's generalization, } \mathrm{e}=1,2,3\end{array}$ \\
\hline \multirow{2}{*}{ Intervi } & $P$ & $P$ & : Researcher \\
\hline & $X$ & $X$ & : Subject of study, $X=A, B, C$ \\
\hline
\end{tabular}

RESULTS AND DISCUSSION

\section{Results}

This section presents the answers of each student on the written test and interview which are supported by the results of the video documentation. The following is a description of the study results on subject A. Based on Figure 2, subject A first wrote what is known in the problem by writing the numbers 5,10,17 as the number of black circles in the first, second, and third terms respectively. After that, subject A determined the constant difference between consecutive terms of the sequence. After subject A obtained an inconstant difference, subject A redrew the black circles for the first to third terms by paying attention to the existing pattern, then he drew and counted the number of black circles in the fourth term. Furthermore, subject A drew an arrangement of black circles in the 99th term to determine the number of black circles in that term. He obtained a result that the number of black circles in the 99th term is 10,001 . 


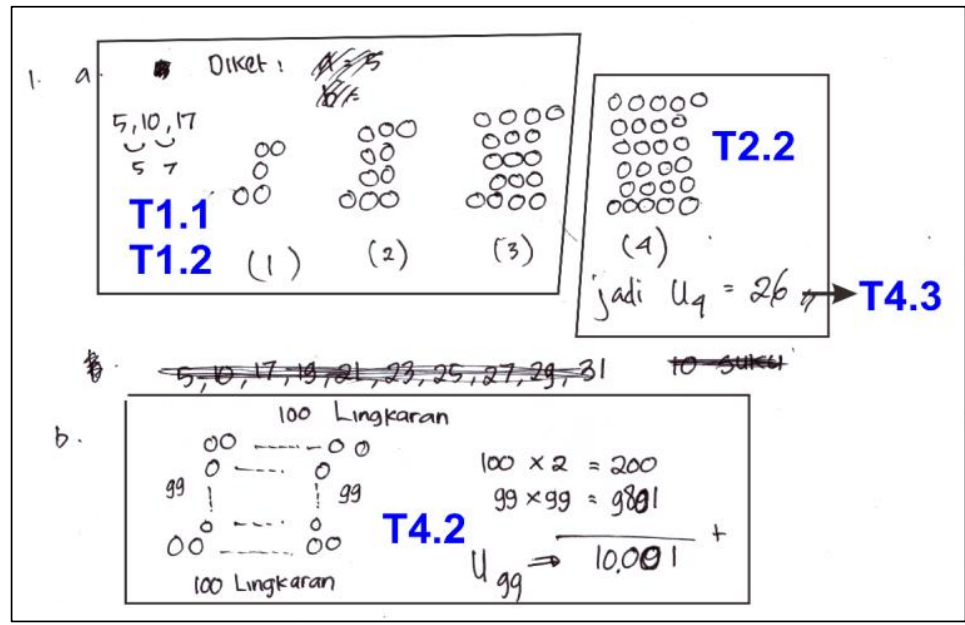

Figure 2. The answer to subject A

Transcript 1 (Transcript of interview with subject A)

$P \quad:$ What is known and asked in the problem?

A : It is known the arrangement of the black circles as many as 5, 10, and 17. We are asked to determine the number of black circles in the fourth term and 99th term and a pattern for determining the number of circles in the 99th term. (T1.1)

$P \quad:$ What strategies did you use to solve the problem?

$A$ : Because these circles form a pattern, I looked for the difference in the number of circles first, and it turned out that the difference was not constant. As a consequence, I determined the number of circles in the fourth term manually. But for the 99th term, I determined it by predicting the existing pattern. (T1.2)

$P \quad:$ Please describe the pattern you predicted!

A : I divided the arrangement of the circles in each term into three parts (upper horizontal row, lower horizontal row, and middle part). In the upper horizontal row part, the first term has two circles, the second term has three circles, and the third term has four circles. It can be interpreted that the number of circles always increases by one circle for the top horizontal row part. This also applies to the lower horizontal row part. As for the middle part, the first term has one circle, the second term has four circles, and the third term has nine circles. It can be interpreted as a quadratic sequence, which is $1,4,9$ or $1^{2}, 2^{2}, 3^{2}$. (T2.1)

$P \quad:$ For the number of circles in this fourth term, are you sure about the results you have obtained? If so, please explain your reasons!

A : Yes, I am sure, because to find out the number of circles in the fourth term, I counted them from the picture I have made. In addition, to draw the circles in this fourth term, I observed the pattern of the arrangement of the circles in the first to the third term. (T2.2)

$P \quad$ : Please explain how you would generalize the pattern in the sequence $\left(U_{n}\right) !$

A : I divided the arrangement of the circles in each term into three parts as I have mentioned earlier. In the upper horizontal line, the first term has two circles, the second term has three circles, and the third term has four circles. The number of circles in each term for that part always increased by one circle. This means that for the upper horizontal row part, there are $n$ +1 circles in the n-th term. Likewise with the lower horizontal row part has the same pattern as the upper horizontal row part. In the middle part, the first term has a circle, the second term has four circles, and the third term has nine circles. This forms a quadratic sequence. Consequently, for the middle part, there are $n^{2}$ circles in the $n$-th term. Thus, the number of circles in the $n$-th term is the sum of $n+1$ (the number of circles in the upper horizontal row part), $n+1$ (the number of circles in the lower horizontal row part), and $n^{2}$ (the number of circles in the middle part). (T3.1)

$P \quad:$ So, what is the general pattern that can be used to determine the number of circles in the n-th term?

$A \quad: n+1+n+1+n^{2}$ (T3.2) 
$P \quad:$ How many circles are in the 99th term?

A : There are 10,001 circles $\mathbf{( T 4 . 2 )}$

$P \quad$ : Are you sure of all the answers you get? If so, please explain your reasons!

$A$ : Yes, I am sure, because what I found and calculated is correct

$P \quad$ Then, have you double-checked your work?

A : No, I have not double-checked my work (T4.1)

$P \quad$ : Please state the conclusion of your work!

A : There are 26 black circles in the fourth term and 10,001 black circles in the 99th term (T4.3)

Based on Transcript 1, subject A presented semiotics in the form of a word (spoken communication) in almost all mathematical generalization indicators, except for the indicator T4.1 because subject A did not double-check his work so that no word was stated by subject A. When subject A solved the problem in the written test, there were a gesture and symbols that he showed at the perception of generality stage (T1.1 and T1.2). The presence of gesture and symbols which correspond to the indicator T1.1 can be seen in Figure 3 and Figure 4, while the gesture and symbols which correspond to the indicator T1.2 can be seen in Figure 5 and Figure 6.

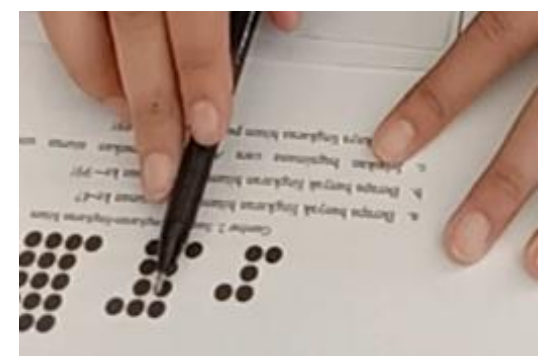

Figure 3. Pointing gesture of subject $\mathrm{A}$ in T1.1

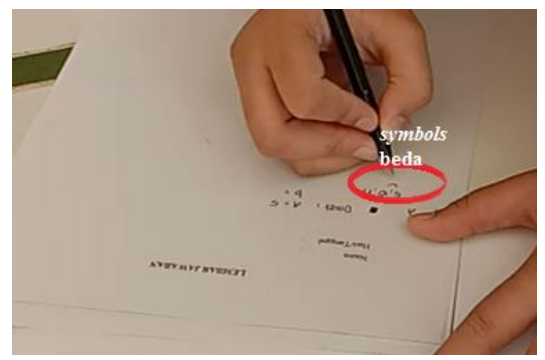

Figure 5. Symbols and representational gesture of subject $\mathrm{A}$ in T1.2

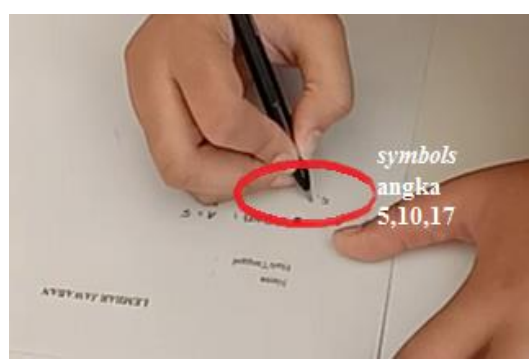

Figure 4. Symbols and representational gesture of subject $\mathrm{A}$ in T1.1

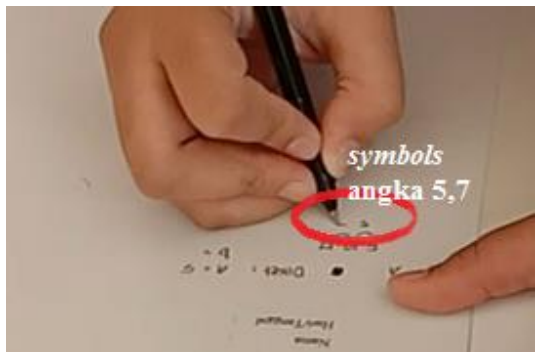

Figure 6. Symbols and writing gesture of subject A in $\mathrm{T} 1.2$

Figure 3 and Figure 4 show that there are pointing and representational gestures performed by subject A when calculating and writing numeric symbols, namely " $5,10,17$ " which respectively represent the number of circles in the first three terms of the sequence. Meanwhile, Figure 5 shows the presence of a representational gesture in representing the difference in the number of circles in the first and second terms and the second and third terms with a symbol. Furthermore, Figure 6 shows that there is a writing gesture in writing symbols in the form of the numbers, namely " 5,7 " (the difference between the number of circles in the first and second terms and between the number of circles in the second and third terms) accompanied by the word (spoken communication), namely "five" and "seven".

Based on Figure 2, there is a gesture that appears at the expression of generality stage (T2.1 and $\mathrm{T} 2.2$ ), while symbols only appear in T2.2 because in T2.1 subject A did not answer it in written form. The presence of a gesture in T2.1 can be seen in Figure 7, while the presence of a gesture and symbols in T2.2 can be seen in Figure 8 and Figure 9. 
Jurnal Riset Pendidikan Matematika, 8 (1), 2021 - 9

Ihda Mutimmatul Fitriyah, Yuni Arrifadah, Siti Lailiyah

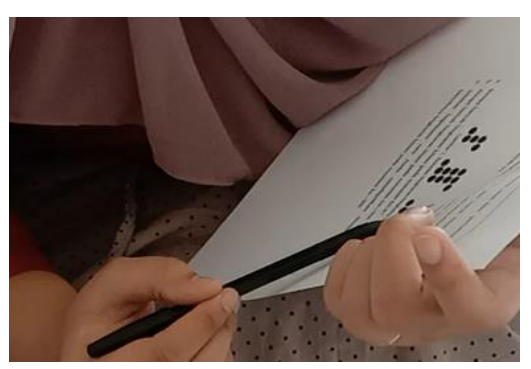

Figure 7. Pointing gesture of subject A in T2.1

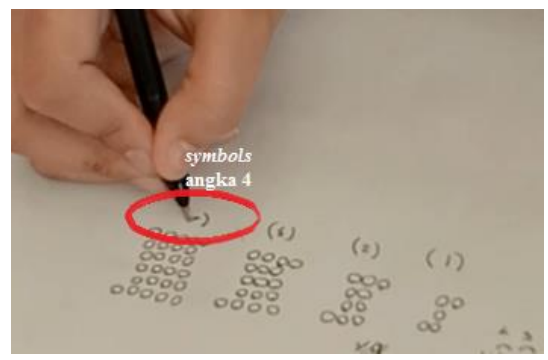

Figure 8. Symbols and representational gesture of subject $\mathrm{A}$ in T2.2

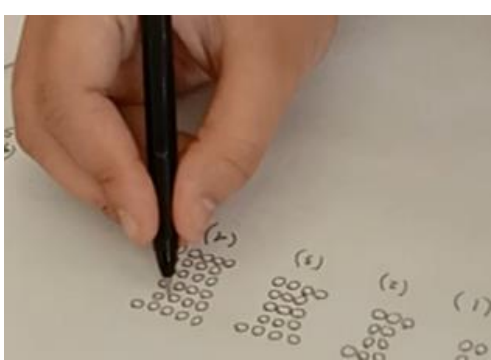

Figure 9. Pointing gesture of subject A in T2.2

Figure 7 shows that there is a pointing gesture when subject A explained the circle arrangement pattern in the problem. Whereas Figure 8 and Figure 9 show that there is a pointing and representational gesture when the subject counted the number of circles in the fourth term and wrote a symbol in the form of a number, namely " 4 " below the fourth circle arrangement representing the fourth term of the sequence.

At the stage of symbolic expression of generality, subject A did not process it in written form but only expressed it during the interview, which resulted in no symbols appearing. However, for the gesture, subject A only showed it in T3.1 when interviewed by researchers. The presence of a gesture in T3.1 can be seen in Figure 10. Figure 10 shows that there is a pointing gesture made by subject A when he explained how to generalize. Subject A made his pen as a pointer tool during generalization.

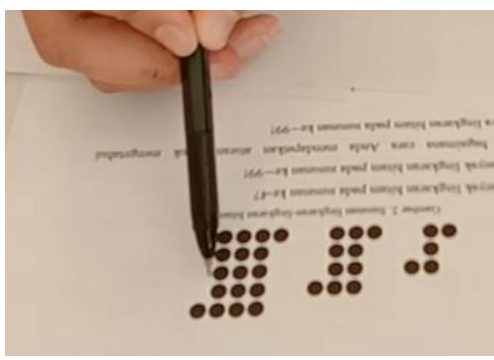

Figure 10. Pointing gesture of subject $A$ in T3.1

Based on Figure 2, the gesture and symbols that appear at the manipulation generality stage are only in T4.2. This happens because, in T4.1, subject A did not re-check his work and in T4.3 subject A drew conclusions not in written form but spoken form during the interview. The presence of a gesture and symbols in T4.2 can be seen in Figure 11 to Figure 14. 


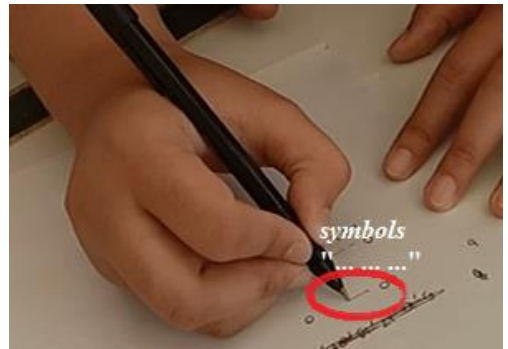

Figure 11. Symbols and first representational gesture of subject $\mathrm{A}$ in $\mathrm{T} 4.2$

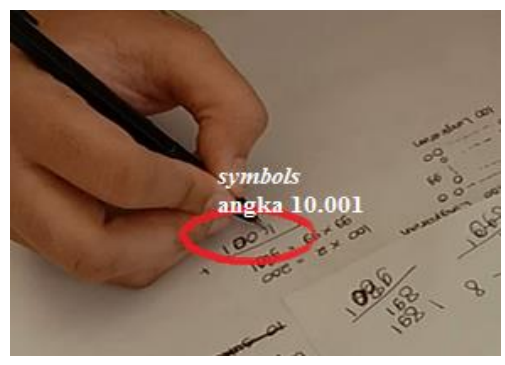

Figure 13. Symbols and writing gesture of subject A in $\mathrm{T} 4.2$

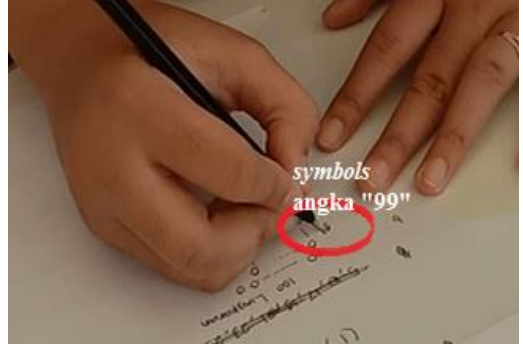

Figure 12. Symbols and second representational gesture of subject A in T4.2

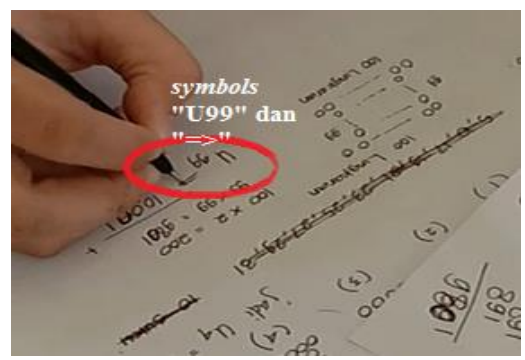

Figure 14. The third representational gesture of subject $\mathrm{A}$ in T4.2

Figure 11 to Figure 14 present the existence of (1) representational gesture when the subject wrote the symbol "........", wrote a word in the form of "100 circles", and wrote a numeric symbol in the form of "99" which represent the arrangement of the circles in the 99th term drawn by subject A; (2) representational gesture when the subject wrote the symbol " $U_{99}$ " and " $\Rightarrow$ " next to the symbol " 10,001 " which means the number of circles in the 99th term is 10,001; and (3) writing gesture when the subject wrote a numeric symbol in the form of 10,001 accompanied by the words "one zero zero zero one".

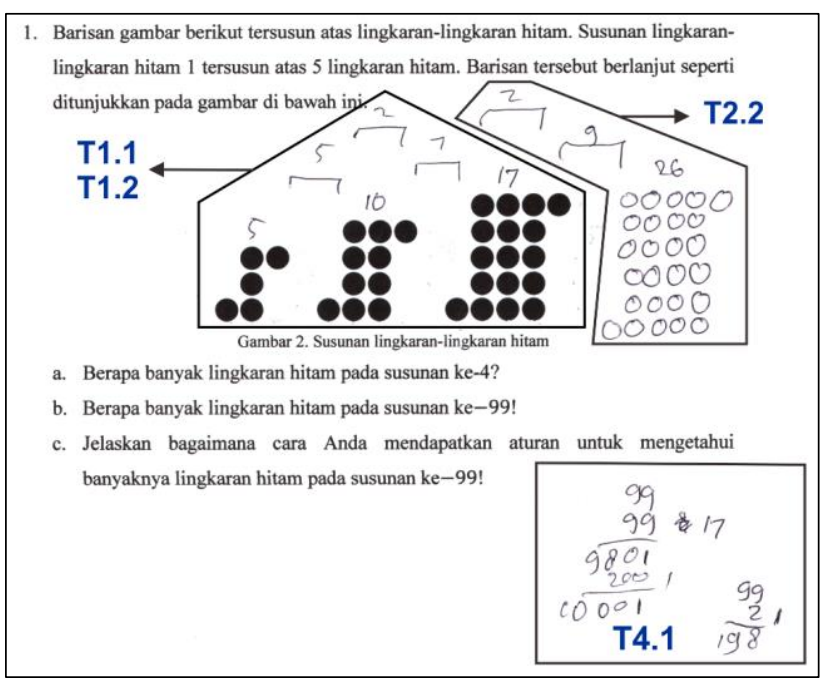

Figure 15. The problem sheet of subject B

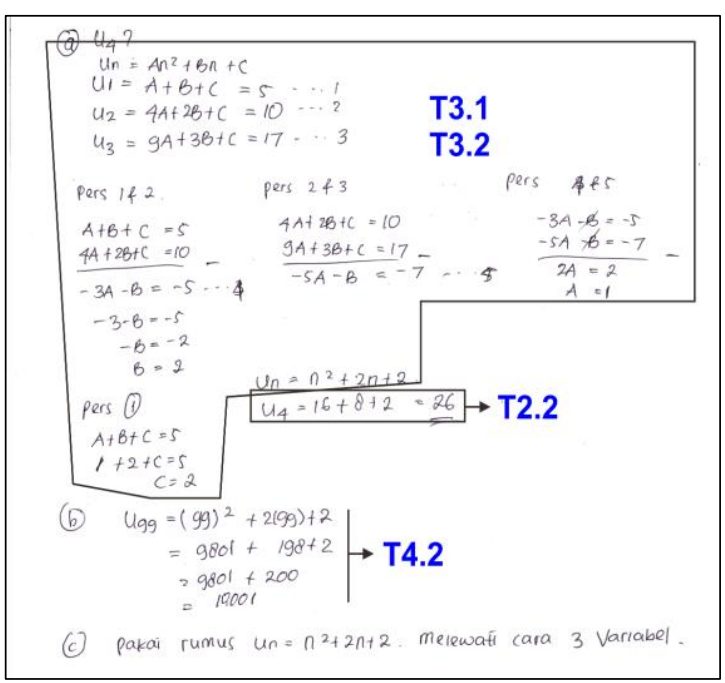

Figure 16. The answer of subject $B$

The next discussion is the semiotics of problem-solving in Mason's generalization carried out by subject B. Based on Figure 15 and Figure 16, subject B first wrote what is known on the problem sheet by writing the numbers $5,10,17$ as the number of circles in the first to third terms respectively. Determining the difference in the number of circles between two consecutive terms was the second step taken by subject B. After knowing that the difference is not constant, subject B decided to use the formula $U_{n}=A n^{2}+B n+C$ to obtain a general pattern $\left(U_{n}\right)$. After obtaining the general pattern, subject B determined $U_{4}$ by substituting $n=4$ to the general pattern that has been obtained. Subject B drew an arrangement of circles for the fourth term by considering the pattern of the arrangement of circles in the first to third terms. The final step taken by subject $B$ was to determine the number circles 
in the 99th term by substituting $n=99$ into the general pattern that has been found so that the result that he obtained is 10,001 circles.

Transcript 2 (Transcript of interview with subject B)

$P \quad:$ What is known and asked in the problem?

$B$ : It is known that the number of circles in the first term is five, in the second term is 10, and in the third term is 17. It is asked the number of circles in the fourth term, the number of circles in the 99 term, and how to get a pattern to determine the number of circles in the 99th term. (T1.1)

$P \quad:$ What strategies did you use to solve the problem?

$B$ : Because I saw that the number of circles in the first term to the third term, which in my opinion, formed a pattern, I used a strategy of determining the difference between two successive terms (T1.2)

$P \quad:$ Please explain the pattern you mean!

$B$ : The number of circles in the first term is five, in the second term is 10, and in the third term is 17. Furthermore, the difference between the number of circles in the first and second terms is five, and the difference between the number of circles in the second and third terms is seven. The difference between five and seven is two. (T2.1)

$P \quad:$ For the number of circles in this fourth term, are you sure about the results you have obtained? If so, please explain your reasons!

$B$ : Since the number of circles in the fourth term I got from drawing the circles manually and from calculating them with the formula yielded the same result, I am confident in my answer. (T2.2)

$P \quad:$ Please explain how you would generalize the pattern in the sequence $\left(U_{n}\right)$ !

$B$ : I used the formula $U_{n}=A n^{2}+B n+C$ where $n=1,2$, 3. I substituted the value of $n$ into the formula so that I obtained $U_{1}=A+B+C=5, U_{2}=4 A+2 B+C=10$, and $U_{3}=9 A+3 B$ $+C=17$. I solved these three equations using the elimination and substitution method so that I obtained $A=1, B=2, C=2$ which I then substituted back to the $U_{n}$ formula and got the general pattern, namely $U_{n}=n^{2}+2 n+2$ (T3.1)

$P \quad:$ So, what is the general pattern that can be used to determine the number of circles in the nth term?

$B \quad: n^{2}+2 n+2(\mathbf{T 3 . 2})$

$P \quad:$ What did you do after you got that general pattern?

$B$ : I determined the number of circles in the fourth term and then I determined the number of circles in the 99th term (T4.2)

$P \quad:$ Are you sure of all the answers you get? If so, please explain your reasons!

$B$ : Because I have double-checked the answer, especially to make sure the number of circles is in the fourth term, I drew the circles manually then counted them and the answer was the same as what I calculated using the formula. So, I am sure.

$P \quad$ Then, have you double-checked your work?

$B \quad$ No, I have not double-checked my work (T4.1)

$P \quad$ : Please state the conclusion of your work!

B : The fourth term has 26 circles, while the 99th term has 10,001 circles (T4.3)

Based on Transcript 2, subject B presents semiotic in the form of a word (spoken communication) in all indicators of mathematical generalization. Furthermore, from Figure 15, it can be seen that there are a gesture and symbols that appear at the perception of generality stage (T1.1 and T1.2). The presence of gesture and symbols in T1.1 can be seen in Figure 17, while in T1.2 can be seen in Figure 18 and Figure 19. 


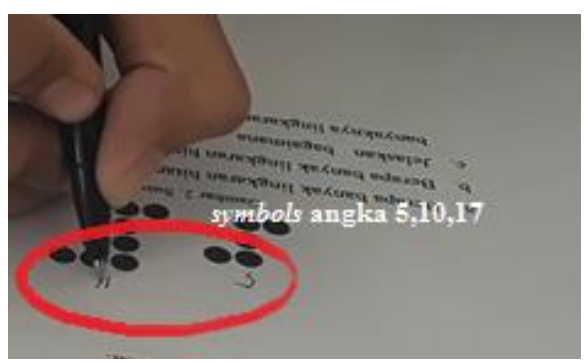

Figure 17. Symbols and representational gesture of subject B in T1.1

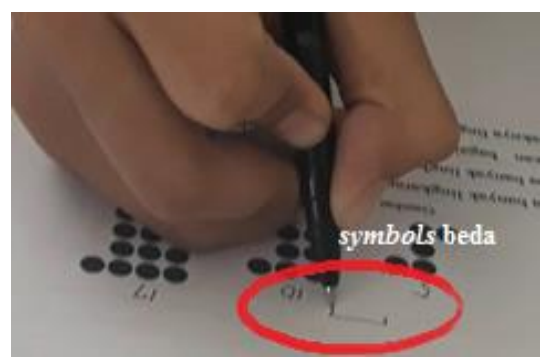

Figure 18. Symbols and representational gesture of subject B in T1.2

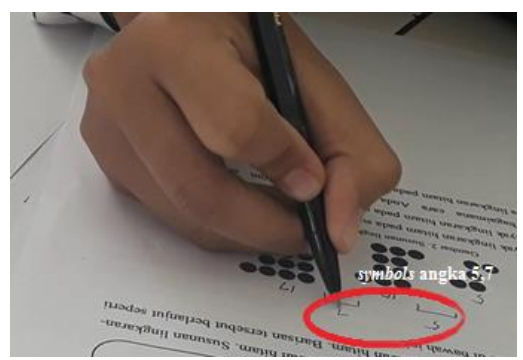

Figure 19. Symbols and writing gesture of subject B in $\mathrm{T} 1.2$

Figure 17 shows that there is a representational gesture in numeric symbols, namely " $5,10,17$ " which represents the number of circles in the first three terms of the sequence respectively. Meanwhile, from Figure 18 and Figure 19, it can be seen that there are representational and writing gestures when the subject wrote symbols, both signs and numbers "5, 7, 2", accompanied by the words "five", "seven", and "two", where the two symbols represent the difference of the number of circles.

Based on Figure 15 and Figure 16, there is a gesture that appears at the expression of generality stage (T2.1 and T2.2). Meanwhile, symbols only appear in T2.2 because at T2.1 subject B did not answer them in written form. The presence of gestures in T2.1 can be seen in Figure 20, while the presence of a gesture and symbols in T2.2 can be seen from Figure 21 to Figure 24.

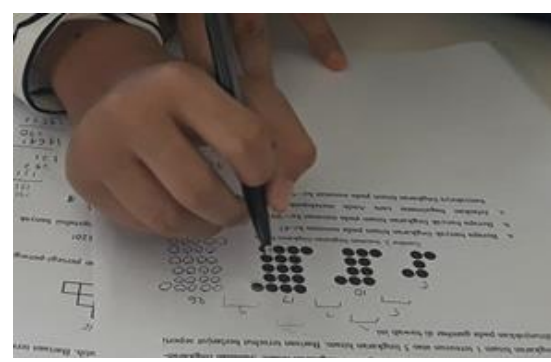

Figure 20. Pointing gesture of subject $B$ in $T 2.1$

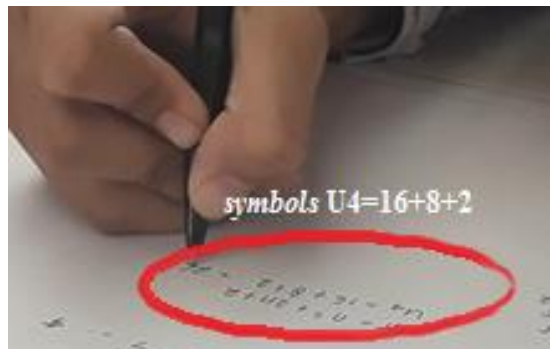

Figure 21. Symbols and first writing gesture of subject B in T2.2

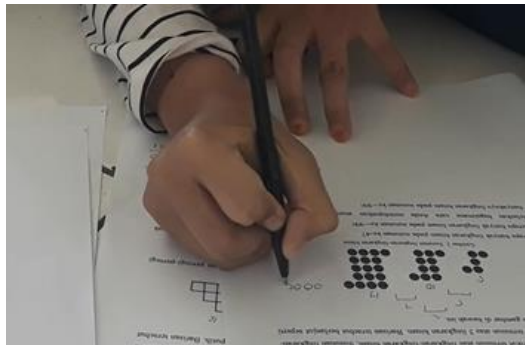

Figure 22. Second writing gesture of subject $B$ in $\mathrm{T} 2.2$ 


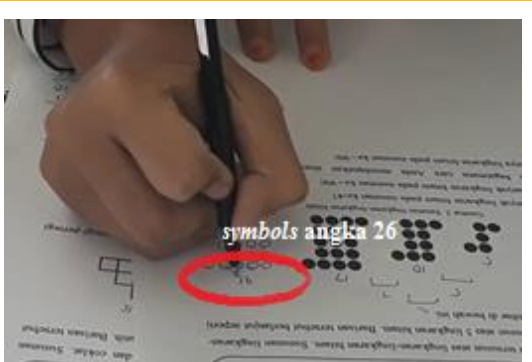

Figure 23. Symbols, representational, and writing gesture of subject B in T2.2

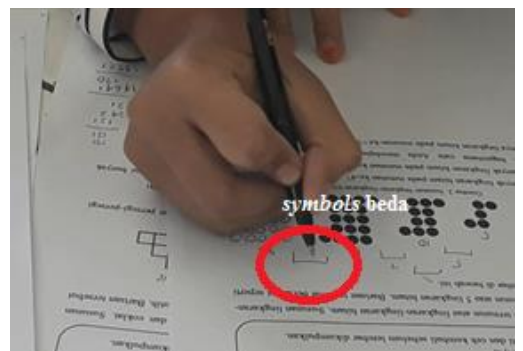

Figure 24. Symbols and representational gesture of subject B in T2.2

Figure 20 shows a pointing gesture when subject B explained the circle arrangement pattern on the problem. Figure 21 and Figure 22 show a writing gesture when the subject wrote the symbol " $U_{4}=$ $16+8+2$ " accompanied by a word in the form of the phrase "sixteen plus eight plus two", "sixteen plus eight, twenty-four, twenty-four plus two, twenty-six", and when the subject made the arrangement of circles in the fourth term accompanied by words in the form of "one, two, three, four, five".

Figure 23 shows that there are representational and writing gestures when the subject represented the number of circles in the fourth term with the numeric symbol in the form of " 26 " accompanied by a word in the form of the spoken expression "twenty-six". Meanwhile, Figure 24 shows that there is a representational gesture when the subject wrote a symbol that represents the difference between the number of circles in the third and fourth terms.

Based on Figure 16, there are a gesture and symbols that appear in the symbolic expression of generality (T3.1 and T3.2). The presence of gesture and symbols in T3.1 can be seen from Figure 25 to Figure 28, while in T3.2 can be seen in Figure 29.

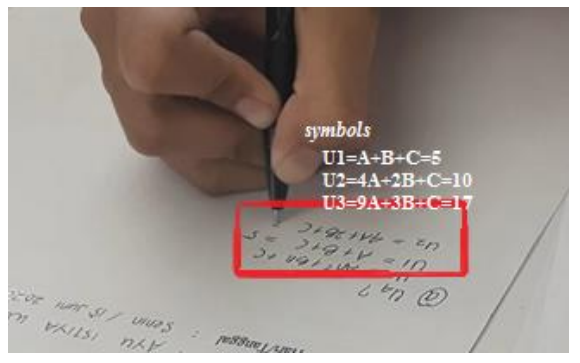

Figure 25. Symbols and first representational gesture of subject B in T3.1

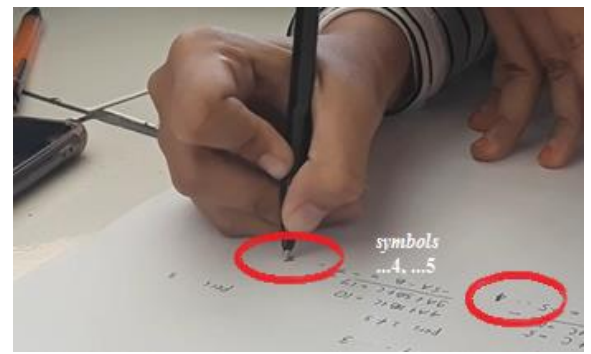

Figure 27. Symbols and third representational gesture of subject B in T3.1

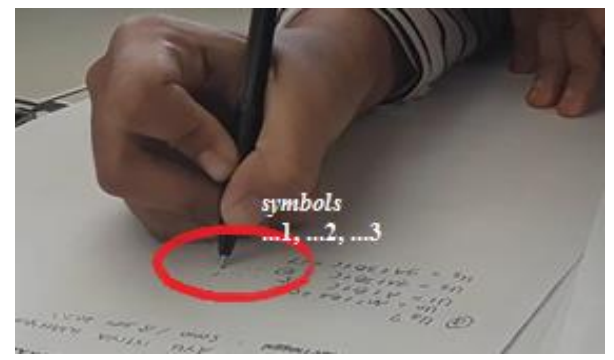

Figure 26. Symbols and second representational gesture of subject B in T3.1

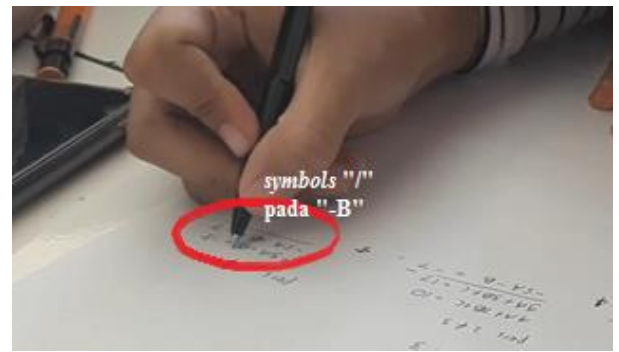

Figure 28. Symbols and fourth representational gesture of subject B in T3.1 


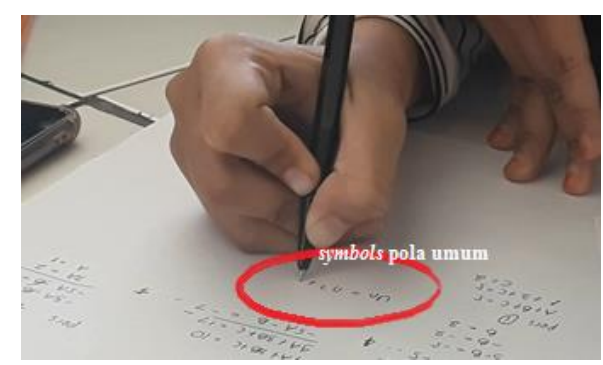

Figure 29. Symbols and representational gesture of subject B in T3.2

Figure 25 to Figure 28 present representational gesture in the symbols in the form of " $U_{1}=A+$ $B+C=5 ; U_{2}=4 A+2 B+C=10$ and $U_{3}=9 A+3 B+C=17$ " that are derived from " $U_{n}=A n^{2}+B n$ $+C$ " with $U_{1}=5, U_{2}=10, U_{3}=17$, in the symbols in the form of " $\ldots 1, \ldots 2, \ldots 3, \ldots 4$, dan $\ldots .$. " that represent the order of equation from fist equation to fifth equation, and in eliminating the symbol " $-B$ " in both equation 4 and equation 5. Meanwhile, Figure 29 shows that there is a representational gesture in the symbol " $U_{n}=n^{2}+2 n+2$ " that is derived from " $U_{n}=A n^{2}+B n+C$ " with $A=1, B=2$, dan $C=$ 2.

Based on Figure 15 and Figure 16, it can be seen that some signs and symbols only appear at the manipulation stage in T4.1 and T4.2. Because in T4.3 the subject did not conclude the solution of his problem-solving in written form, but in spoken form during the interview. A gesture and symbols in T4.1 can be seen in Figure 30 and Figure 31, while a gesture and symbols in T4.2 can be seen in Figure 32.

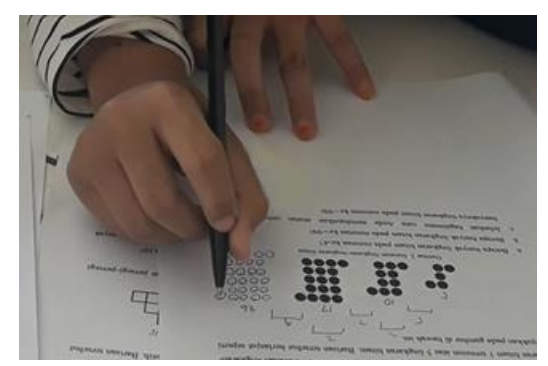

Figure 30. Pointing gesture of subject B in T4.1

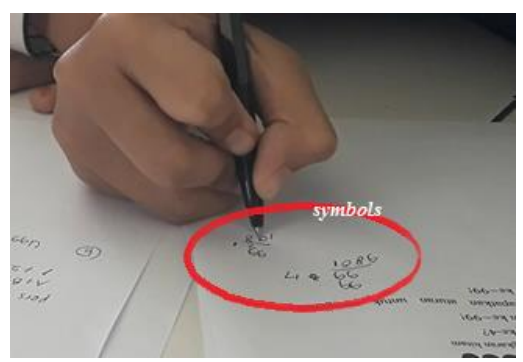

Figure 31. Symbols and writing gesture of subject B in $\mathrm{T} 4.1$

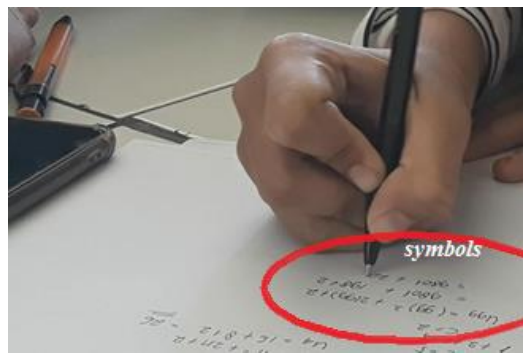

Figure 32. Symbols and writing gesture of subject B in T4.2

Figure 30 and Figure 31 show there is a pointing gesture when the subject counted the number of circles in the fourth term and writing gesture when the subject reconfirmed what he has been calculated by writing the symbols " $99 \times 99=9801$ " and " $99 \times 2=198$ " accompanied by the words "nine eight zero one" and "one hundred and ninety-eight". Furthermore, Figure 32 shows that there is a writing gesture on the symbol " $U_{99}=(99)^{2}+2(99)+2=9801+198+2=9801+200=10001$ " accompanied by the words "one hundred and ninety-eight plus two, ninety thousand eight hundred one plus two hundred, ten thousand and one" at the time of writing. 


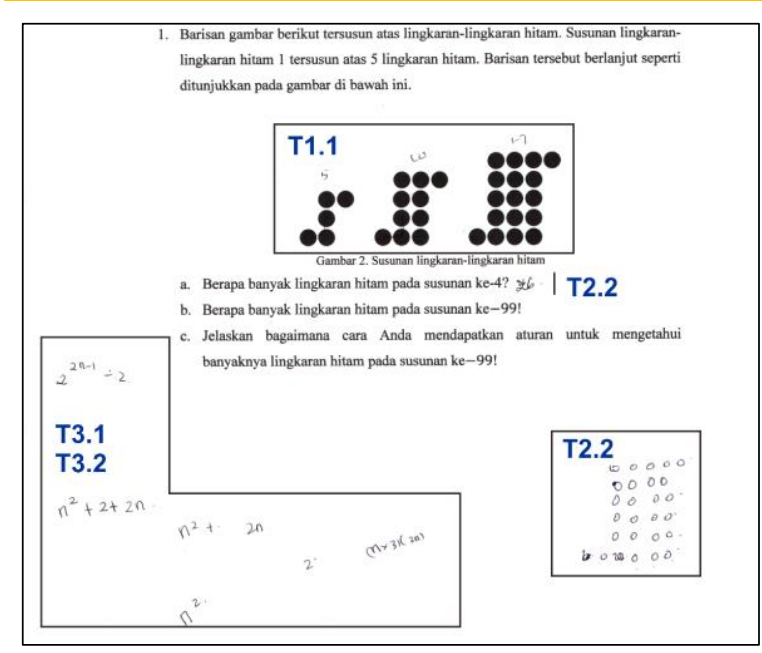

Figure 33. The problem sheet of subject $\mathrm{C}$

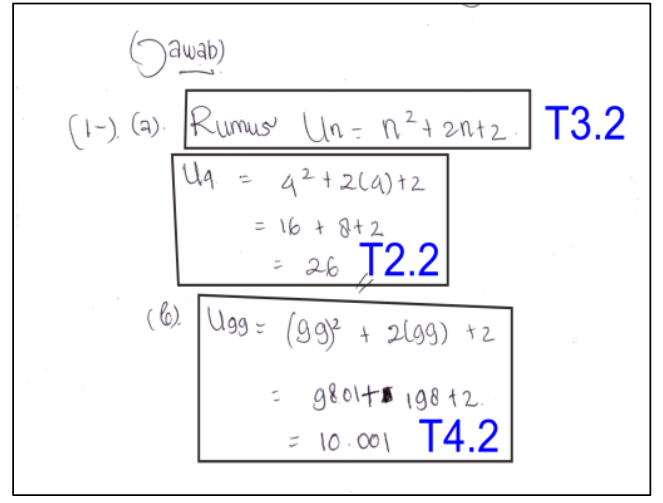

Figure 34. The answer of subject $\mathrm{C}$

Based on Figure 33 and Figure 34, subject $\mathrm{C}$ first wrote what was known on the problem sheet by writing the numbers $5,10,17$ as the number of circles in the first to the third term. The second step taken by subject $\mathrm{C}$ is to look for general patterns $\left(U_{n}\right)$ by trial and error on the problem sheet. After finding the general pattern $U_{n}=n^{2}+2 n+2$, subject $\mathrm{C}$ determined the number of circles in the fourth term by drawing the circles manually and substituting $n=4$ to the general pattern that he has found. Finally, the subject determined the number of circles in the 99th term by substituting $n=99$ into the general pattern so that he obtained 10,001 circles in that term.

Transcript 3 (Transcript of interview with subject C)

$P \quad$ : What is known and asked in the problem?

$C$ : Known that there are five circles in the first term, 10 circles in the second term, and 17 circles in the third term. We were asked to determine the number of circles in the fourth and 99th terms and explain how to obtain a pattern to be able to determine the number of circles in the 99th term. (T1.1)

$P \quad$ : What strategies did you use to solve the problem?

$C \quad$ : Because the black circles are patterned, I discovered the general pattern $\left(U_{n}\right)$ first, then I answered what is asked in the problem (T1.2)

$P \quad$ : Please describe the pattern you mean!

$C$ : The number of circles in the first, second, and third terms always increases. However, I do not know exactly what pattern there might be. (T2.1)

$P \quad:$ For the number of circles in this fourth term, are you sure about the results you have obtained? If so, please explain your reasons!

$C \quad$ : Yes, I am sure because the number of circles in the fourth term that I manually drew and calculated from $U 4$ yielded the same result (T2.2)

$P \quad$ : Please explain how you would generalize the pattern in the sequence $\left(U_{n}\right)$ !

$C \quad$ : I divided the arrangement of the circles in each term into three parts. The lower-left corner and the upper right corner are each composed of one circle and, at each term, the number of these circles does not increase. The middle part forms a square model which is composed of circles 1, 4, and 9 circles (a quadratic sequence) in the first, second, and third terms respectively so that it can be stated that the number of circles in this part is $n^{2}$. The remaining part in each term is composed of 2, 4, and 6 circles (an even number sequence) so it can be said that the number of circles in this part is $2 n$. Therefore, I could obtain the number of circles in the $n$-th term by adding $2, n^{2}$, and $2 n$. (T3.1)

$P \quad:$ So, what is the general pattern that can be used to determine the number of circles in the $n$-th term?

$C: n^{2}+2 n+2(\mathbf{T 3 . 2})$

$P \quad:$ How many circles are in the 99th term?

$C \quad: 10,001$ (T4.2)

$P \quad$ : Are you sure of all the answers you get? If so, please explain your reasons! 
$C$ : I am sure of the $U_{n}$ result that I have calculated. So, my results must be correct regarding the number of circles in the fourth and 99th terms.

$P \quad:$ Then, have you double-checked your work?

$C$ : No, I have not double-checked my work (T4.1)

$P \quad$ : Please state the conclusion of your work!

$C$ : In the fourth term, there are 26 circles and there are 10,001 circles in the 99th term (T4.3)

Based on Transcript 3, subject $\mathrm{C}$ expressed the word (spoken communication) in almost all indicators of mathematical generalization except in the indicator T4.1. In this indicator, subject $\mathrm{C}$ did not double-check on his solution to the problem so that no word appeared. Figure 33 shows that there are gesture and symbols that appear at the level of perception of generality (T1.1). The presence of a gesture and symbols in T1.1 can be seen in Figure 35 and Figure 36.

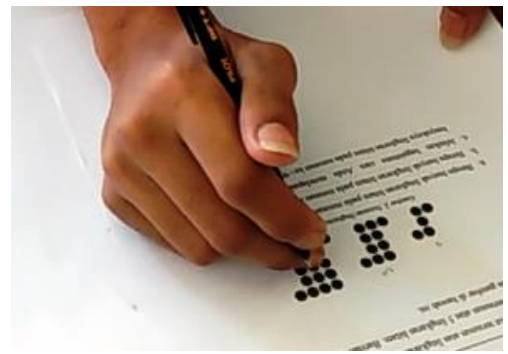

Figure 35. Pointing gesture of subject $\mathrm{C}$ in $\mathrm{T} 1.1$

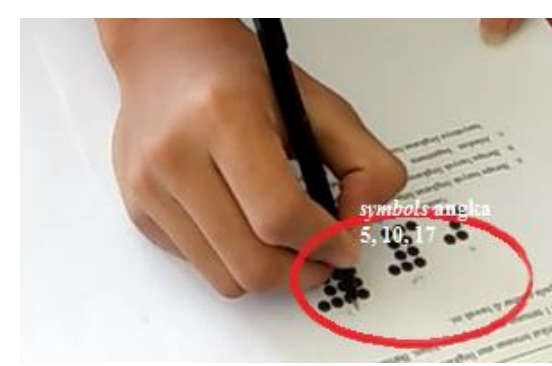

Figure 36. Symbols and representational gesture of subject $\mathrm{C}$ in $\mathrm{T} 1.1$

Figure 35 and Figure 36 show the pointing gesture and representational gesture when the subject counted the number of circles in the first three terms of the sequence and writes the numeric symbols in the form of " $5,10,17$ " which represent the number of circles in each of these terms. Subject C used the index finger of his right hand as a pointer tool during the counting process.

It is the same with the perception of the generality stage, based on Figure 33 and Figure 34 in the expression of generality stage, subject $\mathrm{C}$ only showed gesture and symbols in T2.2. The presence of a gesture and symbols in T2.2 can be seen in Figure 37 and Figure 38.

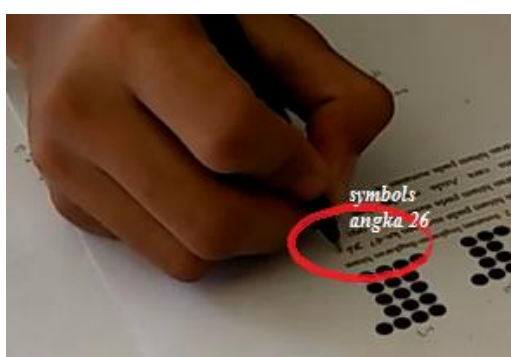

Figure 37. Symbols, representational gesture, and writing gesture of subject $\mathrm{C}$ in $\mathrm{T} 2.2$

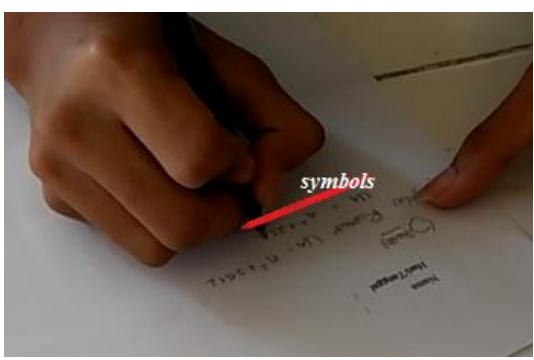

Figure 38. Symbols and representational gesture of subject $\mathrm{C}$ in $\mathrm{T} 2.2$

Figure 37 shows the representational and writing gestures when the subject represented the number of circles in the fourth term with the symbol " 26 " accompanied by the words "twenty-six". Whereas Figure 38 shows the representational gesture when the subject wrote the symbol " $U_{4}=4^{2}+$ $2(4)+2=16+8+2=26$ " as a result of the representation of " $U_{n}=n^{2}+2 n+2$ ".

Based on Figure 33 and Figure 34, some symbols appear in the symbolic expression of generality (T3.1 and T3.2), while a gesture only appears in T3.1. The presence of a gesture in T3.1 can be seen in Figure 39. 


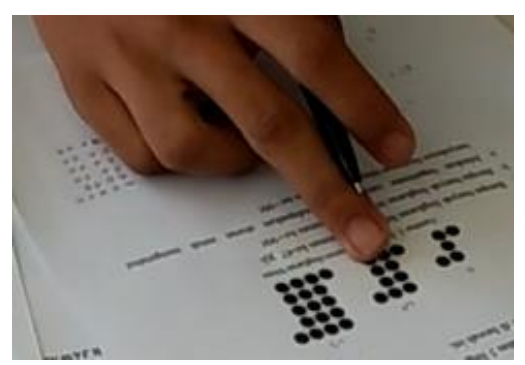

Figure 39. Pointing gesture of subject $\mathrm{C}$ in T3.1

Figure 39 shows there is a pointing gesture when the subject explained how to generalize. Subject $\mathrm{C}$ made the middle finger of his right hand a pointer tool during the generalization process. While the symbols that appear in T3.1 and T3.2 (see Figure 33) include " $2^{(2 n-1)}-2$ ", " $n^{2}+2 n$ ", " $n$ ", " 2 ", " $(n \times 3)$ $(2 n)$ ", and " $U_{n}=n^{2}+2 n+2$ ". The symbol was written by subject C to generalize to obtain a general pattern that he considered to be true.

Figure 33 and Figure 34 show that there are gesture and symbols that only appear at the manipulation generality stage in T4.2 because in T4.1 subject $\mathrm{C}$ did not double-check at all and in $\mathrm{T} 4.3$ subject $\mathrm{C}$ did not draw a conclusion in written form but in the form of words (spoken communication) during the interview. The presence of gestures and symbols in T4.2 can be seen in Figure 40. Figure 40 shows the representational gesture of subject $C$ when writing the symbol " $U_{99}=(99)^{2}+2(99)+2=9801$ $+198+2=9801+200=10001$ " as a result of the representation of " $U_{n}=n^{2}+2 n+2$ ".

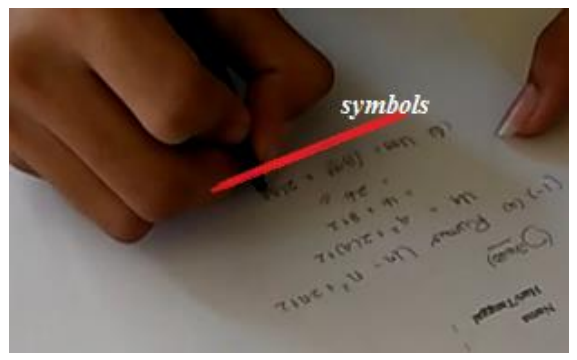

Figure 40. Symbols and representational gesture of subject $\mathrm{C}$ in $\mathrm{T} 4.2$

\section{Discussion}

The following is a summary of a semiotics of mathematics problem-solving in Mason's generalization which has been described in the results section. Table 6 shows that the three subjects can bring up semiotics even though not as a whole in the generalization process. There is no semiotic appearance at several stages because the subject passes or skips several stages in the generalization process. For example, in T4.1 where only one subject raises the three semiotics in double-checking the solutions, but not the other two subjects who are satisfied and sure of the solutions obtained. What these two subjects do is in line with the opinion of Utami and Wutsqa (2017, p. 174) which states that students do not double-check their answers because they are satisfied with the answers they have obtained. Furthermore, in T4.3, the three subjects only show semiotics of a word and do not show semiotics of gesture and symbols. This is because they do not conclude the solutions to the problem in written form, but only in spoken form during the interview.

The three types of gestures (pointing, representational, and writing) during the generalization process were raised by the three subjects from the first to the last stage. In one stage or one indicator, students can bring up more than one type of gesture simultaneously. This proves that gesture has its own role in the process of generalizing patterns. This is following the opinion of Cook et al. (2017) that gestures have a positive impact on learning in several domains, such as mathematics, science, and foreign language.

Based on Table 6, in Mason's generalization, students raise a gesture in the perception of generality (T1.1 and T1.2) and expression of generality (T2.1 and T2.2) stages. As for the symbolic expression and manipulation of generality stages, students only bring up a gesture in one indicator at each of these stages, namely making generalizations (T3.1) and solving problems using the results of generalizations (T4.2). 
Jurnal Riset Pendidikan Matematika, 8 (1), 2021 - 18

Ihda Mutimmatul Fitriyah, Yuni Arrifadah, Siti Lailiyah

Table 6. Summary of a semiotics of mathematics problem-solving in Mason's generalization

\begin{tabular}{|c|c|c|c|c|}
\hline \multirow{2}{*}{$\begin{array}{l}\text { Semiotics } \\
\text { component }\end{array}$} & \multirow{2}{*}{$\begin{array}{l}\text { Code for indicators of } \\
\text { Mason's generalization }\end{array}$} & \multicolumn{3}{|c|}{ Subject code } \\
\hline & & Subject A & Subject B & Subject C \\
\hline \multirow[t]{9}{*}{ Gesture } & T1.1 & $\checkmark$ & $\checkmark$ & $\checkmark$ \\
\hline & T1.2 & $\checkmark$ & $\checkmark$ & - \\
\hline & T2.1 & $\checkmark$ & $\checkmark$ & - \\
\hline & T2.2 & $\checkmark$ & $\checkmark$ & $\checkmark$ \\
\hline & T3.1 & $\checkmark$ & $\checkmark$ & $\checkmark$ \\
\hline & T3.2 & - & $\checkmark$ & - \\
\hline & $\mathrm{T} 4.1$ & - & $\checkmark$ & - \\
\hline & T4.2 & $\checkmark$ & $\checkmark$ & $\checkmark$ \\
\hline & $\mathrm{T} 4.3$ & - & - & - \\
\hline \multirow[t]{9}{*}{ Word } & T1.1 & $\checkmark$ & $\checkmark$ & $\checkmark$ \\
\hline & $\mathrm{T} 1.2$ & $\checkmark$ & $\checkmark$ & $\checkmark$ \\
\hline & $\mathrm{T} 2.1$ & $\checkmark$ & $\checkmark$ & $\checkmark$ \\
\hline & $\mathrm{T} 2.2$ & $\checkmark$ & $\checkmark$ & $\checkmark$ \\
\hline & T3.1 & $\checkmark$ & $\checkmark$ & $\checkmark$ \\
\hline & T3.2 & $\checkmark$ & $\checkmark$ & $\checkmark$ \\
\hline & $\mathrm{T} 4.1$ & - & $\checkmark$ & - \\
\hline & T4.2 & $\checkmark$ & $\checkmark$ & $\checkmark$ \\
\hline & $\mathrm{T} 4.3$ & $\checkmark$ & $\checkmark$ & $\checkmark$ \\
\hline \multirow[t]{9}{*}{ Symbols } & T1.1 & $\checkmark$ & $\checkmark$ & $\checkmark$ \\
\hline & $\mathrm{T} 1.2$ & $\checkmark$ & $\checkmark$ & - \\
\hline & $\mathrm{T} 2.1$ & - & - & - \\
\hline & $\mathrm{T} 2.2$ & $\checkmark$ & $\checkmark$ & $\checkmark$ \\
\hline & T3.1 & - & $\checkmark$ & $\checkmark$ \\
\hline & T3.2 & - & $\checkmark$ & $\checkmark$ \\
\hline & $\mathrm{T} 4.1$ & - & $\checkmark$ & - \\
\hline & $\mathrm{T} 4.2$ & $\checkmark$ & $\checkmark$ & $\checkmark$ \\
\hline & $\mathrm{T} 4.3$ & - & - & - \\
\hline
\end{tabular}

The three subjects raised semiotics of word, whether in the spoken or written form, during the generalization process, from the first to the last stage. However, it is different from other types of semiotics, if it is seen from Table 6 , it can be seen that in the generalization process, semiotics of word appears more frequently and occur more because whatever words or sentences the subject says or writes during the generalization process is one of the subject's attempts to solve the problem. This is following the opinion of Radford (2007, p. 95) that spoken or written words or sentences, gestures, and observations are students' efforts to carry out the process of generalizing patterns.

Based on Table 6, in Mason's generalization, students raise semiotics of a word in the perception of generality (T1.1 and T1.2), expression of generality (T2.1 and T2.2), and symbolic expression of generality (T3.1 and T3). .2). As for the manipulation of the generality stage, students generate semiotics of words in two of the three indicators at this stage, namely solving problems using the results of generalizations (T4.2) and drawing conclusions (T4.3).

As with gesture and word, symbols are also raised by all students from the first stage of generalization to the last stage. The form of the symbols that the students present during the generalization process cannot be guessed, but the presence of these symbols shows the student's effort in understanding the problem of pattern generalization. This is in accordance with the opinion of Oers (2010, p. 31) that the existence of symbols in problem-solving is an effort of students to understand the problem. Hashemi (2013, p. 211) also emphasized that algebraic and symbolic strategies will often be used by students in generalizing patterns in depth.

Based on Table 6, in Mason's generalization, students raise semiotics of symbols in the perception of generality (T1.1 and T1.2) and symbolic expression of generality (T3.1 and T3.2). As for the stages of the expression of generality and manipulation of generality, students only generate semiotics of symbols in one indicator at each of these stages, namely calculating the next term using the identification result (T2.2) and solving the problem using the generalization result (T4.2). 
The results of this study indicate that each student has different ways and forms in bringing up semiotics in solving a problem and making a generalization. This can be an alternative for teachers to find out the extent to which students can understand and solve a problem. Moreover, the results of this study support the opinion expressed by Oers (2010) and Radford (2007) that the existence of symbols, spoken or written words or sentences, gestures, and observations are students' efforts in understanding the process of generalizing patterns. The quality and ability of students in learning mathematics will increase if students are allowed to understand the process of generalizing patterns and get used to solving problems that require them to make generalizations. Making generalizations is one form of inductive reasoning in which reasoning is one of the five competencies that should be developed in students through mathematics learning (NCTM, 2000).

This study was limited to the senior high school level with relatively few students and only involved students who have high mathematical abilities. Other than that, the gesture types were limited to a pointing gesture, representational gesture, and writing gesture. Future research is expected to reach higher education levels, consider all levels of students' mathematical abilities, and consider more diverse types of gestures. The results of this study which show that students have different processes in generalizing can be taken into consideration for teachers in improving the quality of the mathematics learning process, especially to promote the skill of making generalizations of each student through the implementation of certain learning model or method and presentation of certain mathematics problems.

\section{CONCLUSION}

Based on the results of the study and discussion, it can be concluded that students can show the semiotics in the form of gesture, word, and symbols in Mason's generalization process. However, at several stages or indicators, students do not show semiotics. The absence of semiotics in several stages or indicators is not because students cannot show the semiotics, but because students pass or skip these stages. At the stage of perception of generality, semiotics in the form of gesture, word, and symbols can appear simultaneously. However, for the stage of expression of generality, symbolic expression of generality, and manipulation of generality students do not show three semiotics simultaneously at each stage.

By understanding the fact that the semiotics and generalization processes carried out by students are different, it is hoped that it can be taken into consideration by teachers in developing learning design or model that is more appropriate so that students have opportunities to develop their generalizations in the future. It is hoped that there will be further research based on the results of this study to improve the quality of education because this study only focuses on students with high mathematical abilities. As a consequence, the results of this study cannot be generalized thoroughly without distinguishing students' mathematical abilities. Therefore, future research is expected to carry out further studies on the semiotics of problem-solving in Mason's generalization without differentiating students based on their mathematical abilities.

\section{REFERENCES}

Alibali, M. W., \& Nathan, M. J. (2012). Embodiment in mathematics teaching and learning: Evidence from learners' and teachers' gestures. The Journal of The Learning Sciences, 21(2), 247-286. https://doi.org/10.1080/10508406.2011.611446

Anggoro, B. S. (2016). Meningkatkan kemampuan generalisasi matematis melalui discovery learning dan model pembelajaran peer led guided inquiry [Development of mathematical generalization skills through discovery learning and peer-led guided inquiry learning models]. Al-Jabar: Jurnal Pendidikan Matematika, 7(1), 11-20. https://doi.org/10.24042/ajpm.v7i1.23

Barbosa, A., Palhares, P., \& Vale, I. (2007). Patterns and generalization: The influence of visual strategies. In D. Pitta-Pantazi \& G. Philippou (Eds.). Proceedings of the Fifth Congress of the European Society for Research in Mathematics Education, pp. 844-851. https://www.academia.edu/1425435/Patterns_and_generalization_the_influence_of_visual_strat egies

Cook, S. W., Friedman, H. S., Duggan, K. A., Cui, J., \& Popescu, V. (2017). Hand gesture and mathematics learning: Lessons from an avatar. Cognitive Science, 41(2), 518-535. https://doi.org/10.1111/cogs.12344 
Damayanti, N. W. (2018). Profil gesture mahasiswa dalam representasi diagonal sisi dan diagonal ruang pada kubus [Profile of students' gesture in representing diagonal of a cube]. EDU-MAT: Jurnal Pendidikan Matematika, 6(2), 171-177. https://doi.org/10.20527/edumat.v6i2.568

Dwijayanti, I., Budayasa, I. K., \& Siswono, T. Y. E. (2019). Students' gestures in understanding algebraic concepts. Beta: Jurnal Tadris Matematika, 12(2), 133-143. https://doi.org/10.20414/betajtm.v12i2.307

Fadiana, M., Amin, S. M., \& Lukito, A. (2018). Profil generalisasi berdasarkan perspektif semiotik siswa operasional konkret dan operasional formal [Generalization profiles based on semiotic perspectives of students' concrete operations and formal operations]. Jurnal Ilmiah Pendidikan Matematika, 3(2), 99-106. https://doi.org/10.26877/jipmat.v3i2.2517

Faradiba, S. S., Sadijah, C., \& Rahardjo, S. (2016). Identification of mathematics anxiety through gesture. Education in the 21th Century: Responding to Current Issues. International Conference on Education. Universitas Negeri Malang, pp. 881-889.

http://pasca.um.ac.id/conferences/index.php/ice/article/view/119/131

Handayani, S., Putri, R. I. I., \& Somakim, S. (2015). Pemanfaatan lego pada pembelajaran pola bilangan [The utilization of lego in learning number patterns]. Jurnal Didaktik Matematika, 2(1), 21-32. http://jurnal.unsyiah.ac.id/DM/article/view/2383/2250

Hashemi, N. (2013). Generalization in the learning of mathematics. The 2nd International Seminar on Quality and Affordable Education. https://humanities.utm.my/education/wpcontent/uploads/sites/6/2013/11/291.pdf

Ibraheem, N. A., \& Khan, R. Z. (2012). Vision based gesture recognition using neural networks approaches: A review. International Journal of Human Computer Interaction (IJHCI), 3(1), 114. https://www.cscjournals.org/manuscript/Journals/IJHCI/Volume3/Issue1/IJHCI-34.pdf

Inganah, S., \& Subanji, S. (2013). Semiotik dalam proses generalisasi pola [Semiotics in the process of generalizing patterns]. KNPM V, Himpunan Matematika Indonesia.

https://docplayer.info/38722000-Semiotik-dalam-proses-generalisasi-pola.html

Lesmana, L. A., Hidayat, W., \& Rohaeti, E. E. (2018). Meningkatkan kemampuan generalisasi matematik dan kepercayaan diri siswa SMP dengan pendekatan metaphorical thinking [Development of the mathematical generalization skills and self-confidence of junior high school students with a metaphorical thinking approach]. Jurnal Pembelajaran Matematika Inovatif, 1(5), 863-872. https://doi.org/10.22460/jpmi.v1i5.p863-872

Marion, M., Zulkardi, Z., \& Somakim, S. (2015). Desain pembelajaran pola bilangan menggunakan model jaring laba-laba di SMP [Number pattern learning design using a spider web model in junior high school]. Jurnal Kependidikan, 45(1), 44-61. https://journal.uny.ac.id/index.php/jk/article/view/7185/6195

Mason, J. (1996). Expressing generality and roots of algebra. In N. Bednarz, C. Kieran, \& L. Lee (Eds.), Approaches to algebra: Perspectives for research and teaching. https://doi.org/10.1007/978-94009-1732-3_5

Mason, J., Burton, L., \& Stacey, K. (2010). Thinking mathematically (2nd ed.). Pearson. http://mehrmohammadi.ir/wp-content/uploads/2019/11/Thinking-Mathematically.pdf

Ministry of Education and Culture. (2016). Peraturan Menteri Pendidikan dan Kebudayaan Nomor 24 Tahun 2016 tentang Kompetensi Inti dan Kompetensi Dasar Pelajaran Pada Kurikulum 2013 pada Pendidikan Dasar dan Pendidikan Menengah [Regulation of the Minister of Education and Culture Number 24 of 2016 on Core Competencies and Basic Competencies of Subjects in the Curriculum 2013 in Primary and Secondary Education].

Moleong, L. J. (2013). Metodologi penelitian kualitatif [Qualitative research methodology] (rev ed.). Remaja Rosdakarya.

NCTM. (2000). Principles and standards for school mathematics. Author.

NCTM. (2020). Principles and Standards for School Mathematics. Author. 
Octriana, I., Ilma, R. I. P., \& Nurjannah. (2019). Penalaran matematis siswa dalam pembelajaran pola bilangan menggunakan PMRI dan LSLC [Mathematical reasoning of students in learning number patterns using PMRI and LSLC]. Jurnal Pendidikan Matematika, 13(2), 131-142. https://doi.org/10.22342/jpm.13.2.6714.131-142

Oers, B. V. (2010). Emergent mathematical thinking in the contet of play. Educational Studies in Mathematics, 74, 23-37. https://doi.org/10.1007/s10649-009-9225-x

Radford, L. (2007). Iconity and contraction: A semiotic investigation of form of algebraic generalizations of patterns in different context. ZDM Mathematics Education, 4O(1), 83-96. https://doi.org/10.1007/s11858-007-0061-0

Ramdhani, S. (2018). Kemampuan generalisasi mahasiswa pada perkuliahan kapita selekta matematika SMA [The generalization ability of students in the subject of selected topics of mathematics for senior high school]. Jurnal Analisa, 4(2), 83-89. https://doi.org/10.15575/ja.v4i2.3926

Ruhama, M. A. H., Sa'dijah, C., As'ari, A. R., \& Sisworo. (2018). Pointing gesture and speech of teachers in mathematics learning according to information, initiation, and feedback. Journal of Physics: Conference Series, 1028, 1-5. https://doi.org/10.1088/1742-6596/1028/1/012151

Sadieda, L. U., Lailiyah, S., Kusaeri, K., \& Adaniyah, W. (2018). Exploring student's pattern generalization strategy in solving prism sticker problem. Beta: Jurnal Tadris Matematika, 11(2), 131143. https://doi.org/10.20414/betajtm.v11i2.174

Sardila, V. (2016). Analisis semiotika pada tunjuk ajar melayu sebagai pendekatan pemahaman makna dalam komunikasi [Semiotic analysis on Malay teaching pointers as an approach to understanding meaning in communication]. Jurnal Risalah, 27(2), 87-96. https://doi.org/10.24014/jdr.v27i2.2517

Sari, N. I. P., Subanji, S., \& Hidayanto, E. (2016). Diagnosis kesulitan penalaran matematis siswa dalam menyelesaikan masalah pola bilangan dan pemberian scaffolding [Diagnosis of students' mathematical reasoning difficulties in solving number pattern problems and providing scaffolding]. Konferensi Nasional Penelitian Matematika dan Pembelajarannya (KNPMP I). https://publikasiilmiah.ums.ac.id/handle/11617/6979

Setiawan, Y. E., Purwanto, P., Parta, I. N., \& Sisworo, S. (2020). Generalization strategy of linear patterns from field-dependent cognitive style. Journal on Mathematics Education, 11(1), 77-94. https://doi.org/10.22342/jme.11.1.9134.77-94

Sumbo, T. (2009). Semiotika komunikasi visual [Semiotics of visual communication]. Jalasutra.

Suryaningrum, C. W. (2018). Why do students make errors when solving problem in semiotic representation? The 1st Annual International Conference on Mathematics, Science, and Education (ICoMSE 2017), 218, 8-11. https://doi.org/10.2991/icomse-17.2018.3

Tarasenkova, N., \& Kovalenka, O. (2015). Content and semiotic features of mathematical problems used as a means of training the primary school education students. American Journal of Educational Research, 3(12B), 31-35. https://doi.org/10.12691/education-3-12B-7

Utami, R. W., \& Wutsqa, D. U. (2017). Analisis kemampuan pemecahan masalah matematika dan selfefficacy siswa SMP negeri di Kabupaten Ciamis [An analysis of mathematics problem solving ability and self-efficacy students of junior high school in Ciamis Regency]. Jurnal Riset Pendidikan Matematika, 4(2), 166-175. https://doi.org/10.21831/jrpm.v4i2.14897 